\title{
Tourist Behavioural Intentions towards Gastronomy Destination: Evidence from International Tourists in Indonesia by Serli Wijaya
}

Submission date: 06-Jul-2019 10:04PM (UTC+0700)

Submission ID: 1149625168

File name: Manuscipt_without_authors_-_Tourist_Behavioural_Intentions.docx (43.08K) Word count : 6249

Character count: 37131 


\title{
Tourist Behavioural Intentions towards Gastronomy Destination: Evidence from International Tourists in Indonesia
}

\begin{abstract}
Culinary tourism offers tourists to learn new cultures through their experiences with local food of the visited destinations. Although the concept of experience quality and tourist satisfaction in the context of culinary tourism have been discussed in many previous studies, these variables have not been linked to destination experience satisfaction. The aim of this study was to investigate the effect of culinary experience quality on behavioural intentions in Indonesia, with 2 culinary experience satisfaction and destination experience satisfaction as mediating variables. In total, 396 international tourists who travelled to one of the four gastronomy destinations of Denpasar, Solo, Bandung and Yogyakarta participated in the survey. The result showed that the positive culinary experience of international tourists in Indonesia significantly influenced overall destination experience satisfaction, which in turn, led to positive behavioural intentions.
\end{abstract}

Keywords: Culinary experience quality, culinary experience satisfaction, destination experience satisfaction, behavioural intentions, Indonesian local food, international tourists

\section{INTRODUCTION}

Culinary experience has been a prominent concept in the field of tourism industry recently. It is an inseparable aspect of the tourism industry. Tourists visit a place of attraction not only for the place itself but also for the attraction of the local food that a place is offering. While enjoying the 
place, tourists enjoy the food at the same time. Local food is one of the most essential elements of a total destination experience of tourists. Meanwhile, when tourists taste local cuisine, they learn about the destination's culture. The encounter of tasting the local cuisine can be very memorable for them so that it may motivate them to revisit the place in the future (Stone, Soulard, Migacz, \& Wolf, 2018). An empirical study analyzed the relationship between culinary experience quality and behavioural intentions (loyalty) with culinary experience satisfaction as the mediator (Agyeiwaah, Otoo, Suntikul, Huang, 2018). When tourists get good quality of culinary experience, they will be satisfied with the culinary experience which then they will intent to revisit the tourist destination in the future.

Studies by Kivela and Crotts (2006) and Björk and Kauppinen-Räisänen (2016) emphasized the importance of understanding the relationship between food and tourism; there is a relationship between culinary experience and satisfaction of tourists, the culinary experience satisfaction and the destination experience satisfaction (Peštek and Činjarević, 2014). A tourist's experience of local culinary of the visited destinations influences the overall travel experience (Babolian Hendijani, 2016). An impressive and unforgettable culinary experience can also trigger the branding of the destination and most importantly, contribute to the overall satisfaction 8 of tourists. There is also a positive significant relationship between food image and intention to visit a destination (Ab Karim and Chi, 2010). The destination experience satisfaction affects the behavioral intention of tourists. The satisfied tourists tend to visit the same destination and give positive word-of-mouth (Roozbeh, Ng, \& Boo, 2013). However, there was no previous studies to analyze the relationship between culinary experience quality and behavioural intentions with culinary experience satisfaction as well as destination experience satisfaction as the mediating variables. 
Tourism is one of the fastest growing sectors in Indonesia and has become one of the main contributors of Indonesia's gross domestic product (GDP). It accounts for approximately four percent of the total economy. The government of Indonesia wants to have doubled the contribution to eight percent of GDP by 2019 (Indonesia Investment Newsletter, 2018). In 2018, there were roughly 15.81 million international tourists visiting Indonesia. This figure showed a growth rate of $12.58 \%$ above the figure for 2017 (Kemenpar, 2018). Interestingly, based on the distribution of international tourists expenditure, the expenditure for food and beverage becomes the second biggest expenditure around 20.40\% (Badan Pusat Statistik, 2017).

Culinary tourism has been prioritized for development as one of the seven types of special interest tourism in Indonesia. Culinary tourism is expected to be the main factor attaching other tourism activities, considering the fact that tourism is a multi-attribute and prospective sector functioning not only as a gate, but also as the image of Indonesian tourism. The Ministry of Tourism and Creative Economy of Indonesia designated five cities as Indonesia's gastronomy destinations, namely: Bandung, Solo, Yogyakarta, Denpasar and Semarang. The designated of five cities based on six criterias, such as product and main attraction; product and event packaging; service quality; environmental factors; business feasibility; and the role of the government in developing culinary tourism (Kemenpar, 2015). In this case, the study was focused on the four gastronomy destinations, Denpasar, Yogyakarta, Bandung and Solo.

To date, not much research has been done in terms of the relationship between the culinary experience quality, the culinary experience satisfaction, the destination experience satisfaction, and the behavioral intention specfically in Denpasar, Yogyakarta, Bandung and Solo, as the four most prominent tourist destinations of Indonesia. Therefore, the authors are addressed to analyze more deeply about how the culinary experience quality of international 
tourists in Denpasar, Yogyakarta, Bandung and Solo could affect the behavioral intention. This will be very much beneficial for the local government to develop local culinary in Denpasar, Yogyakarta, Bandung and Solo that will give culinary experience for the international tourists. On this basis, the objectives of this study are to:

1. Examine the effect of culinary experience quality on culinary experience satisfaction 2

2. Investigate the effect of culinary experience satisfaction on destination experience satisfaction.

3. Observe the effect of culinary experience quality on the destination experience satisfaction.

4. Examine the effect of culinary experience satisfaction and the destination experience satisfaction on the behavioral intention.

\section{LITERATURE REVIEW}

\section{Culinary Experience Quality}

Food is a basic sustenance for every tourist during their travel. Each tourist needs food when traveling since it is a basic sustenance that must be fulfilled. Regardless of whether culinary activity becomes the main goal or just as a satisfying need during the trip, a person's culinary experience would shape the image of the culinary enjoyed. One's culinary experience could affect the overall experience of the visited destinations (Ignatov and Smith, 2006).

Wijaya, King, Nguyen, \& Morrison (2013) propose a conceptual framework of international visitor dining experiences with local food, by examining the experiences in the course of the pre-, during, and post-dining stages. The pre-dining stage refers to how international visitors foresee their engagement with the various aspects that may concern dining with local food, as well as the prospect of associated experiential outcomes. The during-dining 
stage relates to actual encounters with local food within the destination, as reflected in visitor perceptions of the dining experience. Lastly, the post-dining stage refers to visitor satisfaction and behavioral intentions that emerge after the dining experience has been concluded. It is important to note that culinary experience is subjective, meaning the culinary experience is influenced by the individual's own experience (Sfandla and Björk, 2013). Similar to Wijaya et al.'s (2013) framework, Björk and Kauppinen-Räisänen (2014) depict that culinary experience refers to the process in which each experience occurs in various stages, i.e. before experience (e.g. searching for a restaurant or food), during experience (e.g. meal experience) and after the experience of eating (e.g. purchasing local food as souvenirs. It should also be noted that the culinary experience is something subjective, meaning that the culinary experience is influenced by the individual's own experience. Destination management organizations (DMOs) could use culinary as a representative of cultural experience, status, cultural identity, as well as how to communicate the tourist destinations (Horng, Liu, Chou, and Tsai, 2012). Further, Silkes, Cai, \& Lehto (2013) noted that food could show a unique and most memorable experience for the whole trip.

Andersson and Mossberg (2004) state that culinary experience is multi-dimensional, that is, the measurement of the quality of the culinary experience can not be seen only from one dimension of the food, but there are other dimensions especially in the context of a tourist experience with a culinary region that is never consumed previous. Review of the literature has shown that there are three major dimensions to measure the quality of culinary experience with local food at a destination. These dimensions are: 1) food dimension that relates to attributes of taste, food authenticity and food uniqueness; 2) social dimension that includes the extent of which tourists could interact with the locals and experience the hospitality and distinct culture of 
the host; and 3) place and time dimension that refers to the physical place where the eating experience with local food take place, as well as when the eating experience occurs (Hendijani, Ng, \& Boo, 2013; Peštek and Činjarević, 2014; Wijaya, King, Morrison, \& Nguyen, 2017).

Culinary is an important component of tourism products, and plays an important role in creating an impressive tourist experience (Peštek and Činjarević, 2014). It is viewed as a form of special interest tourism offering "real" travel. Recognized as part of cultural tourism, it provides real learning opportunities by introducing visitors to the new and exciting smells, tastes, and flavors of local cultures (Ignatov \& Smith, 2006). Babolian Hendijani (2016) suggested that by consuming local foods, tourist can conceive the identities and ethnicities of people of a given destination. In terms of cultural point of view, food experience portrays the images of cultural experience, status and cultural identity. Such cultural aspect is usually developed from the unique aspects of food experiences that can only be attained in that particular destination. Therefore, food is something that is deeply rooted in the culture and traditions of a region. Experiencing local foods on vacation is a type of pleasurable sensory experience (Kivela and Crotts, 2006). Foods also provide sensory experiences that enhance the pleasure of a vacation and attract tourists to a destination.

Previous studies have shown that there is an increase in the search for new experiences for consumers (Wang, 2016). While on vacation, tourist will tend to look after new experiences which are never been achieved before, including enjoying traditional, authentic, unique and new food (Björk and Kauppinen- Räisänen, 2013). A variety of food-related characteristics such as preparation, cooking style, presentation, dining customs, food culture, and food consumption can be included to construct experiences that tourist has with food at the destination. Culinary experience is not only influenced by traditional food, but also can be influenced by social aspect, 
external environment, and services provide in a particular destination (Björk and KauppinenRäisänen, 2013). Thus, each of these aspects can make a memorable trip for tourists. The sensory aspects of food enable tourists to experience the culture of a particular country on a deeper level (Babolian Hendijani, 2016).

\section{Culinary Experience Satisfaction}

Many researchers have identified that food experience at a destination can represent an important source of satisfaction for tourists (Babolian Hendijani, 2016). Babolian Hendijani (2016) also 1 found that food has a significant result on tourists' overall satisfaction with the trip. Thus, 1 suggested that a new food experience brings excitement to people's lives, and this experience is considered a means of improving oneself when expectation and satisfaction are combined. Kivela and Crotts (2006) mentioned that food can increase value to the tourist experience and is associated with tourism quality for tourists in search of new experiences that yield a high level of satisfaction. In general, it seems that food significantly contributes to tourists' overall satisfaction.

Satisfaction is commonly viewed as an indicator of experience quality (Ryan, 2002). Satisfaction is not just about the joy of travel experience but also an evaluation that makes the experience as good as it should be. In line with the culinary experience dimensions as described earlier, Björk and Kauppinen-Räisänen (2016) in their study explain that tourist satisfaction towards culinary experience could be measured based on three aspects of: 1) what food or local cuisine being served; where the food is served; and how the food is served.

3 Extensive research has been devoted to investigating the linkage between culinary experience and tourist behavior constructs such as satisfaction, behavioral intention, and loyalty. 
3

A study in Portugal has been accomplished to identify the determinants of international visitor satisfaction with Portugal's gastronomy tourism. It revealed three significant factors: local gastronomy; atmosphere; and food quality and price as the most important determinants of visitors' satisfaction (Correia, Moital, Da Costa \& Peres, 2008). Another empirical study was also conducted in Malaysia confirming that food plays an important and interesting role in enhancing destination experience. A positive culinary experience quality perceived by tourists specifically the first-time travellers indicating culinary satisfaction, which in turn, it can be used to trigger revisit intention (Babolian Hendijani, Sambasivan, $\mathrm{Ng}$, \& Boo, 2013).

3

\section{Destination Experience Satisfaction}

According to Murphy, Pritchard, and Smith (2000), destinations can be viewed as a set of complementary tourism products and services to form travel experience in an area visited by tourists. Tourist perception on the quality of destination experience is determined by 3 infrastructure and destination environment. Service infrastructure consists of a set of products and services that offer a direct experience for travellers when they are in a destination, which includes travel agency services, food service businesses, accommodation and transport services. Destination environment is a component supporting the provision of experience for tourists encompassing: the natural environment, political conditions, availability of technology, economic conditions, and socio-cultural factors of a destination.

Satisfaction in the context of tourism industry is described as tourists' assessment based on experiences they have been through (Sukiman, Omar, Muhibudin, Yussof, \& Mohamed, 2013). The provision and quality of elements such as attractions, public and private facilities, accessibility, human resources, image and character, also price can impact on shaping the 
experience, satisfaction, and also the decision of tourists to travel (World Tourism Organization, 2007). Sukiman et al. (2013) also said that tourist satisfaction can be influenced by the quality of the products (presentation, taste, smell) and the quality of service (place, easy access, friendly staff), which then need tourist emotional reaction as an assessment. The satisfaction of a group of tourist and service facilities in a location is the benchmark for the satisfaction of tourist destinations (Wang, 2016).

In relation to eating experience, $\mathrm{Ab}$ Karim and Chi (2010) contend that tourist's experience with local culinary would affect their perception of the overall experience with the visited destination. Moreover, the perception of tourists towards the experience of destination will have a positive effect on satisfaction, which in turn, could give a positive impact on the intention to revisit the destination and the intention give referrals to others (Barnes, Mattsson \& Sorensen, 2014).

\section{Behavioral Intentions}

Behavioral intentions often stem from a structured decision-making which go through the processes of selecting, delivering, and using products, services, experiences, or ideas in satisfying needs and desires (Babolian Hendijani, et al., 2013). Individuals behavioral intentions sometimes can be viewed by the willingness to use again something that has been used before, to go back to a place where has been visited before, to feel again services that have been enjoyed before, or willingness to share positive informations about a place or a thing to families or acquaintances. This is the result of overall tourist satisfaction (Amoah, Radder, and van Eyk, 2016). Altintzoglou et al., (2016) said that a satisfied tourist will tend to have the urge to tell their acquaintances or relatives about the experience they have just enjoyed in demand for their acquaintances and relatives wanting to have the exact same experience. Sometimes, a positive 
emotion from tourist leaves a positive memory toward a particular destination which then lead the tourist to revisit the place to have the same feeling once again.

Tourist behavioral intentions would lead to his loyalty toward particular destination or tourism-related activity. There are two widely common indicators used to measure behavioral intentions (Prayag, Hosany, \& Odeh, 2013). First is the intention to give referral or recommendations to other people that occurs when tourists are eager to talk about their tourism experiences (word of mouth) to their relatives or friends. Second is revisit intention, meaning that tourists whose tourism experiences are positive would have the tendency travel again to enjoy the destination or to do the same tourism activities as previously he had (Björk, \& Kauppinen-Räisänen, 2014).

Many studies have examined the relationship between variables that affect consumer behavior intentions. Tourist behavior has now focused on tourist satisfaction, as tourist satisfaction influences the decision of tourists to return (Rajaratnam, Nair, Pahlevan Sharif, \& Munikrishnan, 2015). One of the triggers of consumer behavior (in this case tourists) is the satisfaction of tourists to destinations and culinary (Peštek and Činjarević, 2014). Rajaratnam et al. (2015) add that culinary experience demand such emotional response from tourist which will affect towards tourist behavior intentions in the future ahead. Prayag et al. (2013), then suggested that there is a significant relation between tourist satisfaction and behavior intentions.

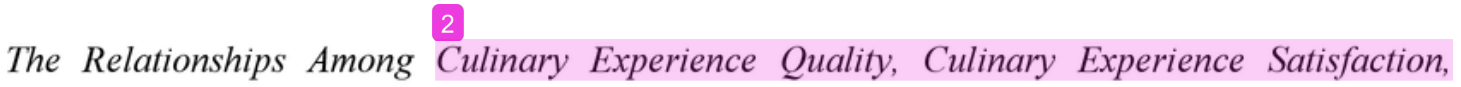
Destination Experience Satisfaction, and Behavioural Intentions

Culinary is one component of tourism products which plays an important role in creating an impressive tourist experience (Peštek and Činjarević, 2014). A tourist who has a strong desire to 
consume traditional foods, will also looking for impressive new culinary experiences (Björk dan Kauppinen-Räsänen, 2014). In addition, Peštek and Činjarević (2014) explained that the culinary experience is a combination of tourist's opinions, the attributes of food, and the response of tourists that involves their feelings. The response is an evaluation of the whole culinary experience, that will assess whether it is good or not. Based on the above explanation, the culinary experience is considered as a phenomenon that not only involves food as a whole but also includes emotions from tourists. The following hypothesis was deducted from the earlier study.

Hypothesis 1: Culinary experience quality (CEQ) has a positive and significant impact on culinary experience satisfaction (CES).

Food experiences are important to destinations. Positive engagement that tourists have with food and drink would lead to memorable dining experience. Such $\underset{7}{7}$ xperiences have been associated with an increase in travel satisfaction and positive word of mouth (Stone, et. al., 2018). Culinary has a role as a national identity. Whereas, culinary will help to present the identity and culture of a destination, and also create perception and opinion about the building views, and destination images (Ab Karim and Chi, 2010). Therefore, Bjök dan KauppinenRaisänen (2014) explained that food plays important role in creating the satisfaction of tourists to a destination. Hence the hypothesis appears as follows:

Hypothesis 2: Culinary experience satisfaction (CES) has a positive and significant impact on the destination experience satisfaction (DES). 
Ab Karim and Chi (2010) stated that food and destinations are inseparable and food can influence the tourist's destination decision. Food is also regarded as a cultural identifier of a destination (Peštek and Činjarević, 2014). In addition, research by Babolian Hendijani, et al. (2013) also confirmed that in Malaysia, food plays an important and interesting role in enhancing destination experience. A positive culinary experience quality perceived by tourists specifically the first-time travelers indicates culinary satisfaction, which in turn, can be used to trigger revisit intention. World Tourism Organization (2007) stated that the culinary experience is one of the attraction factors, which is able to encourage the satisfaction of tourists to a destination. Based on the above discussion, the following hypothesis was proposed as:

Hypothesis 3: Culinary experience quality (CEQ) has a positive and significant impact on the destination experience satisfaction (DES)

Kim, Ritchie \& McCormick (2012) urge that destination managers and tourism businesses should know how to develop a memorable experience is important. A destination that is memorable will have a competitive advantage since it could offer more outstanding and exceptional experiences. Local cuisines of a destination is therefore could be utilised by Destination Management Organizations (DMOs) as a means to represent cultural experience, status, cultural identity, as well as how to communicate the tourist destinations (Horng et al., 2012). Further, Silkes et al. (2013) noted that food could show a unique and most memorable experience of the whole trip. Therefore, Babolian Hendijani, et al. (2013) showed that food could give additional attraction to the destination. Moreover, destination satisfaction does not only trigger the repeated selection of a tourist destination but also affect the tourist's behavior intentions as a whole (Rajaratnam, et. al, 2015). This statement is supported by research from Huang \& Hsu (2009) quoted from Bjök dan Kauppinen-Raisänen (2014) which states that 
travelers apply the memory of the tourist experience in determining travel intentions (for example, the option to revisit a tourist attraction or re-repeat an experience). Furthermore, Babolian Hendijani, et al. (2013) also explain that local food can be used to drive tourism products and trigger repeated travel intentions in a tourist destination. On this basis, the following hypotheses were formulated:

Hypothesis 4: Culinary experience satisfaction (CES) and destination experience satisfaction (DES) has a positive and significant impact on tourist's behavioral intention (BI). Hypothesis 4a: Culinary experience satisfaction (CES) has a positive and significant impact on tourist's behavioral intention (BI).

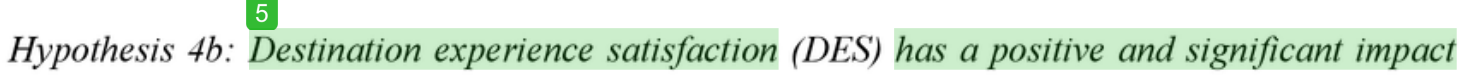
on tourist's behavioral intention (BI).

The reseach model of the study describing the relationships among the latent variables is presented in figure 1 .

\section{Insert Figure 1 here}

\section{METHODOLOGY}

The samples were representative of the indefinite population of international tourists in four cities (Denpasar, Jogjakarta, Solo and Bandung). The sampling process used was purposive sampling meaning that the respondents should be at least 21 years old, and have enjoyed local food during their visit.

The questionnaire was divided into five sections. Section 1 sought information about participant demographics such as gender, age, occupation, the purpose of visit and the length of 
stay. Section 2 contained questions related to the culinary experience quality of domestic tourists in four selected gastronomy cities. In section 3, the participants were requested to state opinions regarding culinary experience satisfaction in the city whereby they visited. Section 4 sought participants' opinions regarding their visited destination experience satisfaction, while the last section, section 5 contained questions related to behavioral intention of international tourists.

The culinary experience quality was measured by three sub-variables, namely food, social and place, and there were adapted from Björk dan Kauppinen- Räisänen (2014). The culinary experience satisfaction were translated to overall satisfaction to food, social interaction and quality of place, which were adapted from Kivela and Crotts (2006); and the destination experience satisfaction was measured by four sub-variables, namely attraction, public and private facilities, human resources, and price, which were adapted from Wang (2016). Behavioral intention was measured by two sub-variables, namely: revisit intention and recommendation intention, of which were adapted from Ab Karim and Chi's (2010) and Rajaratnam et al.'s measurement instruments (2015).

A questionnaire-based survey incorporating a total of 396 international tourists was completed. They were asked: 1) basic profiles relating to demographics and travel characteristics; 2) perceived quality of culinary experience measured by three sub-variables, which are food, social, and place; 3) culinary experience satisfaction were translated to overall satisfaction to food, social interaction and quality of place; 4) destination experience quality was measured by four sub-variables, namely attraction, public and private facilities, human resources, and price. The level of agreement with given statements was assessed by using a seven-point Likert-type scale, with anchors "strongly disagree" as 1 to "strongly agree" as 7 . The study 
applied descriptive statistics to describe the participants' profiles meanwhile Partial Least Square (PLS) path modeling was applied to test the proposed research hypotheses.

\section{FINDINGS}

The participants were $53 \%$ male and $47 \%$ female with majority aged between $21-30$ years old (35\%). Three groups of university students (27\%), house wife (19\%) and employees (19\%) were dominating the total participants. Most of the participants were from Australia (17\%) and France (10\%). Moreover, most of the purpose of visit was for leisure (72\%). Most of the participants travelled with friends (48\%) and they were first time visitors (54\%).

The result of the construct validity testing indicated that all the indicators were valid since all the indicators were above 0.50 . The result of the path analysis is presented in Figure 2 .

\section{Insert Figure 2 here}

The values of the composite reliability and the Cronbach's Alpha value were above the cut-off value of 0.70 which means reliable.

\section{Insert Table 1 here}

The goodness of fit as calculated from the $\mathrm{Q}^{2}$ value. The $\mathrm{Q}^{2}$ value is calculated from the $\mathrm{R}^{2}$ values in table 2 . The value of $\mathrm{Q}^{2}: 1-\left[\left(1-0.613^{2}\right) \times\left(1-0.790^{2}\right) \times\left(1-0.693^{2}\right) \times\left(1-0.408^{2}\right) \times(1-\right.$ $\left.\left.0.475^{2}\right)\right]=0.921=92.1 \%$. It shows that $92.1 \%$ of the change variation of destination experience satisfaction as the independent variable can be explained by culinary experience quality and 
culinary experience satisfaction as the dependent variables while $7.9 \%$ can be explained by other variables which are not analyzed in this research.

Insert Table 2 here 
Moreover, based on the second order analysis on the factors forming the culinary experience quality, it can be seen in figure 1 that food (CEQ-F: 0.889) is the most dominant factor reflecting the culinary experience quality where the uniqueness of the food presentation as the main reflector. While social factor (CEQ-S: 0.832) is another factor reflecting the culinary experience quality where the different way of service as the main reflector. Then dining place factor (CEQ-D: 0.783 ) is the third factor reflecting the culinary experience quality where the dining ambience reflecting the local culture as the main reflector. Furthermore, the main reflector of culinary experience satisfaction is the the quality of the dining place (CES3: 0.816). Whereas the main reflector of destination experience satisfaction is the good value for money (DES8: 0.759). The main reflector of behavioral intention is revisiting the place in the future.

Based on the path coefficients, it showed that the relationships between variables were positive (original sample). From the result of the t-statistic, it indicated that the relationship between customer experience quality (CEQ) and customer experience satisfaction (CES) was positive and significant $(11.638>1.96)$. Also the relationship between customer experience quality (CEQ) and destination experience satisfaction (DES) was positive and significant (5.138 $>$ 1.96). Moreover, the relationship between customer experience satisfaction (CES) and destination experience satisfaction (DES) was positive and significant $(9.316>1.96)$. The relationship between destination experience satisfaction (DES) and behavioral intentions (BI) was also positive and significant $(15.145>1.96)$. Similarly, the relationship between customer experience satisfaction (CES) and behavioral intentions (BI) was positive and significant (2.700 $<1.96)$. Therefore, all the research hypotheses were supported except for hypothesis 3 was also supported. 


\section{Insert Table 3 here}

\section{DISCUSSION AND IMPLICATIONS}

The findings of this study is significant in a way that it contributes to the understanding of the variables influencing the behavioral intentions of the international tourists visiting Indonesia specifically in Denpasar, Solo, Bandung and Yogyakarta. Based on the hypothesis testing, it was confirmed that culinary experience quality (CEQ) positively and significantly influenced both the culinary experience satisfaction (CES) and destination experience satisfaction (DES). It shows that the higher the culinary experience quality, the higher the satisfaction both the culinary and destination experiences. When tourists visit the tourist destinations in Indonesia and they find that the culinary experience is favourable, they will be more likely to be contended with both the culinary experience as well as the destination experience. This is relevant with the previous studies which discover that culinary has a significant role in creating the high-quality traveling experience and making the high satisfaction of the tourists with the tourist destination (Kivela \& Crotts, 2006; Tsai, 2016; Widjaja., et al., 2018).

Furthermore, culinary experience satisfaction (CES) had a positive and significant influence on destination experience satisfaction (DES). It means that the improvement of culinary experience satisfaction will cause the destination experience satisfaction to improve as well. In addition, destination experience experience (DES) itself gave positive and significant influence on behavioral intentions (BI). That is, the higher the satisfaction of the tourists on the destination experience, the higher the intentions of the tourists to revisit the place or to recommend it to others. Furthermore, culinary experience satisfaction also gave a significant effect on behavioral intentions. It means that the improvement of culinary experience satisfaction will result on international tourist intentions to revisit or to recommend the place to others. When tourists enjoy the culinary experience, they will be more likely to be satisfied with the tourist destination and the possibility for them to return to 
the place is higher as well as the intention to recommend the destination to others. This is relevant with the previous study findings that when tourists enjoy local cuisines, they will have unforgettable tourism experiences which will create strong attachment to the tourist destination and they will be more likely to return to the destination or recommend it to others (Kivela \& Crotts, 2006; Tsai, 2016; Kristanti, et al., 2018).

Based on the total effect calculation, the indirect effect that gave the most effect on behavioral intentions was the one which was mediated by culinary experience satisfaction and destination experience satisfaction. It implies that the international tourists are more likely to revisit the place or recommend the place to others if they find that the culinary experience quality is good and they will be satisfied with the culinary experience. As a result, they will also be satisfied with the destination experience which finally will lead to their intention to revisit the place in the future. There are three factors composing the culinary experience quality (CEQ), namely: food factor (uniqueness of the food presentation), social factor (different way of service) and dining place (dining ambience reflecting the local culture). Among the three factors, food factor is the most influential factor reflecting the customer experience quality. In this case, the finding supports the previous studies emphasizing the three major dimensions to assess culinary experience quality, they are: food dimension (food authenticity), social dimension (local people's hospitality), and place and time dimension (dining environment). It was found in the study that culinary experience quality was constructed mainly by unique food presentation in food dimension, different style of service in social dimension and ambience of the dining place in dining place dimension (Tsai \& Lu, 2012; Widjaja, et al., 2018).

Furthermore, the result of this current study is in contrast with the previous study. The previous study findings revealed food quality was the main satisfier indicator of culinary experience satisfaction (Peštek and Činjarević, 2014). While this study found that the quality 
of the dining place appeared to be the main satisfier indicator of culinary experience satisfaction (CES). In terms of destination experience satisfaction, there were three main satisfier indicators constructing the satisfaction, namely: good value for money (DES8), accomodation facility (DES4) and infrastructure (DES3). It indicates that participants who were the international tourists found that they were satisfied with the good value for money, accomodation facility and the infrastructure when visiting Denpasar, Solo, Bandung and Yogyakarta.

Finally, in terms of behavioral intentions, the main indicator was future intention to revisit the place (BI3). It means that the participants are more likely to revisit the place if they find that the culinary experience quality is good, they are satisfied with the culinary experience which then they are also satisfied with the destination experience.

\section{CONCLUSION AND FUTURE RESEARCH}

This study revealed how culinary experience quality contributes to the foreign tourists' behavior intention through culinary experience satisfaction and destination experience satisfaction. It means that the higher the culinary experience quality, the higher the satisfaction both the culinary and destination experiences. The higher the satisfaction of the tourists on the destination experience and culinary experience, the higher the intentions of the tourists to revisit the place or to recommend it to others. The result also highlights the significant role of local food unique presentation on improving tourists' culinary experience quality. In line with the previous studies, these findings confirmed that travelers' positive experience of local food will lead to their satisfaction of the local culinary and the destination, furthermore will increase their intention to recommend and revisit the destination.

Understanding this model will aid government to identify the way to preserve local food and develop it in facing globalization era. In addition, the model will help the 
government to increase the satisfaction of foreign tourist toward local culinary and the destination, in order to attract them to revisit Indonesia. Moreover, the government should enhance the promotion of local food unique presentation particularly to the foreign tourists.

\section{REFERENCES}

Ab Karim, S., \& Chi, C. G. Q. (2010). Culinary tourism as a destination attraction: An empirical examination of destinations' food image. Journal of hospitality marketing \& management, 19(6), 531-555.

Agyeiwaah, E., Otoo, F. E., Suntikul, W., \& Huang, W. J. (2019). Understanding culinary tourist motivation, experience, satisfaction, and loyalty using a structural approach. Journal of Travel \& Tourism Marketing, 36(3), 295-313.

Altintzoglou, T., Heide, M., \& Borch, T. (2016). Food souvenirs: buying behaviour of tourists in Norway. British Food Journal, 118(1), 119-131.

Amoah, F., Radder, L. and van Eyk, M., (2016). Perceived experience value, satisfaction and behavioural intentions: A guesthouse experience. African Journal of Economic and Management Studies, 7(3), 419-433.

Andersson, T. D., \& Mossberg, L. (2004). The dining experience: do restaurants satisfy customer needs?. Food Service Technology, 4(4), 171-177.

Babolian Hendijani, R., Sambasivan, M., Ng, S. I., \& Boo, H. C. (2013). Effect of gastronomy experience on overall satisfaction: differences between backpackers and mass tourists in Malaysia. Reading on Hospitality and Tourism Issues, McGraw Hill, Kula Lumpur, 107-123.

Babolian Hendijani, R. (2016). Effect of food experience on tourist satisfaction: the case of Indonesia. International Journal of Culture, Tourism and Hospitality Research, 10(3), 272-282.

Badan Pusat Statistik, (2017). Katalog BPS 8401011: International visitor arrivals statistics 2017. Retrieved from https://www.bps.go.id, [Accessed $2^{\text {nd }}$ February 2019].

Barnes, S. J., Mattsson, J. \& Sørensen, F. (2014). Destination brand experience and visitor behavior: Testing a scale in the tourism context. Annals of Tourism Research, 48, 121139.

Björk, P., \& Kauppinen-Räisänen, H. (2014). Culinary-gastronomic tourism-a search for local food experiences. Nutrition \& Food Science, 44(4), 294-309.

Björk, P., \& Kauppinen-Räisänen, H. (2016). Exploring the multi-dimensionality of travellers' culinary-gastronomic experiences. Current Issues in Tourism, 19(12), 12601280. 
Correia, A., Moital, M., Da Costa, C. F., \& Peres, R. (2008). The determinants of gastronomic tourists' satisfaction: a second-order factor analysis. Journal of foodservice, 19(3), 164-176.

Horng, J.S., Liu, C.H., Chou, H.Y. and Tsai, C.Y., (2012). Understanding the impact of culinary brand equity and destination familiarity on travel intentions. Tourism Management, 33(4), 815-824.

Ignatov, E., \& Smith, S. (2006). Segmenting Canadian culinary tourists. Current Issues in Tourism, 9(3), 235.

Kementerian Pariwisata dan Ekonomi Kreatif (Kemenpar), (2015). Siaran pers dialog gastronomi nasional dan peluncuran 5 destinasi wisata kuliner unggulan 2015. [online] Available at: http://www.kemenpar.go.id/asp/detil.asp?c $=16 \&$ id $=3024$. [Accessed $20^{\text {th }}$ February 2019].

Kementerian Pariwisata dan Ekonomi Kreatif (Kemenpar), (2018). Statistik wisatawan mancanegara: data kunjungan wisatawan mancanegara bulanan tahun 2018. Retrieved from https://www.kemenpar.go.id, [Accessed $15^{\text {th }}$ February 2019].

Kim, J. H., Ritchie, J. B., \& McCormick, B. (2012). Development of a scale to measure memorable tourism experiences. Journal of Travel Research, 51(1), 12-25.

Kivela, J., \& Crotts, J. C. (2006). Tourism and gastronomy: Gastronomy's influence on how tourists experience a destination. Journal of Hospitality \& Tourism Research, 30(3), 354-377.

Kristanti, M., Jokom, R., Wijaya, S., \& Widjaja, D.C. (2018). Culinary experience towards behavioral intention of domestic tourists in Solo and Bandung, Indonesia. Kinerja, 22 (2), 186-199.

Murphy, P., Pritchard, M. P., \& Smith, B. (2000). The destination product and its impact on traveller perceptions. Tourism management, $21(1), 43-52$.

Peštek, A., \& Činjarević, M. (2014). Tourist perceived image of local cuisine: the case of Bosnian food culture. British Food Journal, 116(11), 1821-1838.

Prayag, G., Hosany, S., \& Odeh, K. (2013). The role of tourists' emotional experiences and satisfaction in understanding behavioral intentions. Journal of Destination Marketing \& Management, 2(2), 118-12.

Rajaratnam, S. D., Nair, V., Pahlevan Sharif, S., \& Munikrishnan, U. T. (2015). Destination quality and tourists' behavioural intentions: rural tourist destinations in Malaysia. Worldwide Hospitality and Tourism Themes, 7(5), 463-472.

Roozbeh, B. H., Ng, S. I., \& Boo, H. C. (2013). Effect of food experience on overall satisfaction: comparison between first-time and repeat visitors to Malaysia. International Food Research Journal, 20(1), 141.

Ryan, C. (2002). Tourism and cultural proximity: Examples from New Zealand. Annals of tourism research, 29(4), 952-971. 
Sfandla, C., \& Björk, P. (2013). Tourism experience network: co-creation of experiences in interactive processes. International Journal of Tourism Research, 15(5), 495-506.

Silkes, C. A., Cai, L. A., \& Lehto, X. Y. (2013). Marketing to the culinary tourist. Journal of Travel \& Tourism Marketing, 30(4), 335-349.

Stone, M. J., Soulard, J., Migacz, S., \& Wolf, E. (2018). Elements of memorable food, drink, and culinary tourism experiences. Journal of Travel Research, 57(8), 1121-1132.

Sukiman, M. F., Omar, S. I., Muhibudin, M., Yussof, I., \& Mohamed, B. (2013). Tourist satisfaction as the key to destination survival in Pahang. Procedia-Social and Behavioral Sciences, 91, 78-87.

Tsai, C.T. (2016). Memorable tourist experiences and place attachment when consuming local food. International Journal of Tourism Research, 18(6). 536-548.

Tsai, C.T. \& Lu, P.H. (2012). Authentic dining experiences in ethnic theme restaurants. International Journal of Hospitality Management. 31, 304-306.

Wang, Y. (2016). More important than ever: Measuring tourist satisfaction. Griffith Institute for Tourism, Griffith University.

Widjaja, D.C., Wijaya, S., Jokom, R., Kristanti, M. (2018). Culinary experience of international tourists in Indonesia: A study on Denpasar and Yogyakarta tourist destinations. Paper presented at the Seventh International Conference on Entrepreneurship and Business Management (ICEBM), Bali.

Wijaya, S., King, B., Nguyen, T. H., \& Morrison, A. (2013). International visitor dining experiences: A conceptual framework. Journal of Hospitality and Tourism Management, 20, 34-42.

Wijaya, S., King, B., Morrison, A., \& Nguyen, T. H. (2017). Destination encounters with local food: The experience of international visitors in Indonesia. Tourism Culture \& Communication, 17(2), 79-91.

World Tourism Organization. (2007). A practical guide to tourism destination management. World Tourism Organization. 


\section{Tourist Behavioural Intentions towards Gastronomy}

Destination: Evidence from International Tourists in Indonesia

ORIGINALITY REPORT

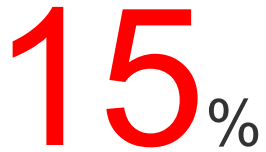

SIMILARITY INDEX
$15 \%$

INTERNET SOURCES
$10 \%$

PUBLICATIONS
$\%$

STUDENT PAPERS

PRIMARY SOURCES

1 www.emeraldinsight.com

Internet Source

2 repository.petra.ac.id

Internet Source

3 vuir.vu.edu.au

Internet Source

4 core.ac.uk

5 ojs.uajy.ac.id

Internet Source

6 Serli Wijaya, Brian King, Thu-Huong Nguyen,

Alison Morrison. "International visitor dining

experiences: A conceptual framework", Journal

of Hospitality and Tourism Management, 2013

Publication 
On 